\title{
A LIBRARIAN'S STROLL THROUGH MILTON'S AFTERLIFE
}

\author{
BY MICHAEL JOSEPH
}

\begin{abstract}
"A Librarian's Stroll through Milton's Afterlife" is a brief gallery tour of our favorite books in the exhibition, The Afterlife of John Milton. They are not necessarily curatorial favorites, assuming curators should want books that best illustrate the arguments underlying their show, nor a reader's favorite-books with the most powerful or influential or recognizable texts. Although all of them do support the theme of the show and possess famous and astonishing texts, our favorites are first and foremost distinctive, one-of-a-kind objects, with their own unique histories and compelling stories. A few of these are modest in scope-amusing anecdotes, or bibliographic jokes-but one or two are truly remarkable.
\end{abstract}

As many of the books in the show were acquired by the Libraries many years ago-at a time when, in order to contribute to a unified national database, university cataloging consisted largely of deriving records of the ideal copy from the Library of Congressthe distinctive qualities of these books were unrecorded and unknown to us. They represent the sort of undiscovered treasures that used to tempt English majors into library schools, before the rise of digitization shifted the grounding of library service away from bibliography.

The exhibition, The Afterlife of John Milton, was a companion to Thomas Fulton's John Milton and the Cultures of Print. It was conceived collaboratively by Dr. Fulton, a Milton specialist, Dr. Kevin Mulcahy, humanities bibliographer, and me, rare books librarian, with the notion of pointing out that John Milton continued to shape and influence English and American literature well after his death in 1674, and to suggest the scope of his influence in a broad survey of great books stretching over two and a half centuries. The larger body of the show resembled the syllabus of a mid-twentieth century intro to English lit, with Pope's The Rape of the Lock (1714), ${ }^{1}$ and his translation of Homer's Iliad, ${ }^{2}$ Joseph Addison's Notes upon the Twelve Books of Milton's Paradise 


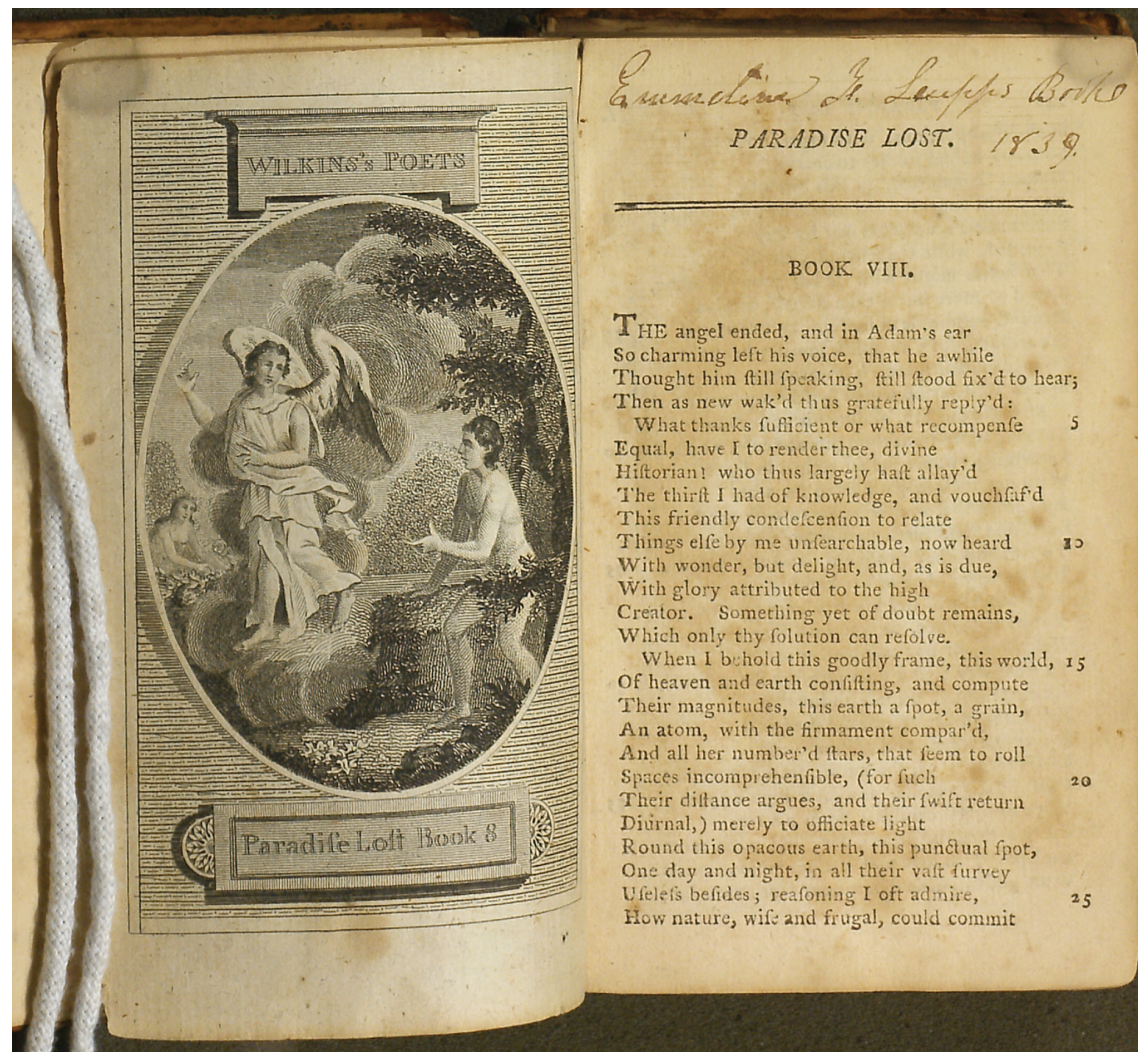

9.1 Vol. 2 of The Poetical Works of John Milton: from the Text of Dr. Newton: in Two Volumes (London: Printed and sold by T. Wilkins, Aldermanbury, MDCCXCIV [1794]). Signed by a childish and nearly undecipherable hand, this cheap, two volume edition of Milton's Poetical Works attests to the poet's presence among young adult readers of the late eighteenth century. 
Lost: Collected from The Spectator, ${ }^{3}$ Johnson's Lives of the Most Eminent English Poets (1790), ${ }^{4}$ Wordsworth's Prelude $(1850)^{5}$ Keats' Endymion, Melville's Moby Dick ${ }^{6}$ and Whitman's Leaves of Grass, $\underline{\underline{8}}$ among other iconic texts. A few twentieth and twenty-first century titles, like Robert Graves' Wife to Mr. Milton, Philip Pullman's The Golden Compass, J. K. Rowling's Harry Potter and the Sorcerer's Stone, and Thomas Pynchon's After the Day, demonstrated that Milton remains not merely an influence on contemporary literature but part of its living tissue, as inseparable from it as vocabulary or parts of speech.

Generally, the texts discussed below are unique copies upon whose pages handwritten notes, inscriptions, even personal letters, cast a backlight on the social history of the library, and occasionally reveal undiscovered details of the Afterlife of John Milton.

\section{Milton, John. The Poetical Works of John Milton: from the Text of} Dr. Newton: in Two Volumes (1794) ${ }^{9}$

Physically the least assuming book in the exhibition-indeed, some early reader has emended "adorned" in the title phrase describing the copperplate engravings to "deformed" - this late eighteenth century small octavo copy of Milton's works endears itself to us because of the suggestion that it was intended for children. The title page bears the signature of "Lady Emmeline [Lascess?]." A contemporary of the publisher Thomas Wilkins, John Newbery, whose life is commemorated by the Newbery medal, had earlier succeeded at his business in St. Paul's Churchyard selling octavos much like this one for children. Beginning in 1744, the publications of Newbery led to the consolidation of the field of children's literature ${ }^{10}$-although what passed or could pass for children's literature varied dramatically, and ran the gamut from abbreviations of Henry Fielding's bawdy novel Tom Jones to accounts of the revelations of children seized on their deathbeds by Calvinist revelations. A pocket-size publication of Milton's poetical works would have appealed to a young audience already attuned to the instructive verse of authors such as John Bunyan and Isaac Watts. Young ladies and gentlemen of a certain position in the world would have received their own copy of Milton not just as an acknowledgement of their importance to society, but as a challenge to rise to the lofty heights of a moral education.

While Thomas Wilkins, the publisher of The Poetical Works is not known as a children's publisher, his religious publications 
geared to improvement pressed at the periphery of children's literature. Another copy of one of The Poetical Works, in the University of Virginia Library, bears the bookplate of Beverley R. Wellford, M.D., and the signature of his mother, Catharine Wellford, with her presentation inscription dated "March 7, 1813." A physician of Richmond, Virginia, Beverley Wellford was born in 1797 and thus received the gift of The Poetical Works when he was only sixteen-perhaps on his sixteenth birthday. Another copy-and I am sorry but the citation eludes me right now-bears the signature of Lady Lucy Leslie-Melville. The book is dated 1822, two years before her marriage. While nobody would argue that Milton's poetical works represents the Harry Potter of their day, these

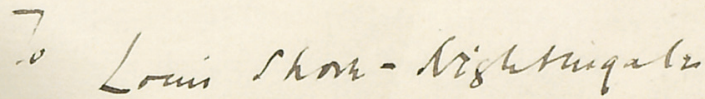

$$
\begin{aligned}
& \text { The 215. Franc 1903 }
\end{aligned}
$$

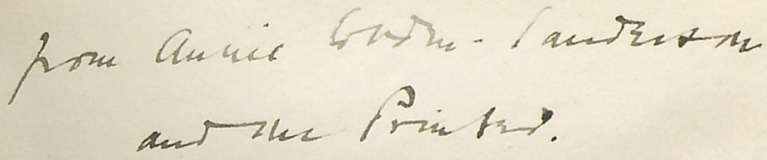

9.2 Front free-endpaper of Alfred Tennyson's, Seven Poems and Two Translations (London: Doves Press, 1902), bearing a presentation inscription by Annie Cobden-Sanderson to Louis-Shore Nightingale, the nephew of Florence Nightingale. Annie Cobden-Sanderson was co-founder of the Doves Press, and the wife of Thomas J. Cobden-Sanderson, who, together with William Morris, was one of the two most influential figures in the Typographic Renaissance of the late nineteenth century

volumes provide us with evidence that during the early decades of the nineteenth century, they came to represent a point on the historical continuum of young adult reading.

\section{Tennyson, Alfred. Seven Poems \& Two Translations (1902) ${ }^{11}$}

Having grounded our discussion of Tennyson's debt to Milton by including a first edition (1833) of Tennyson's Palace of Art, in which he places Milton in the company of Shakespeare, Dante, and Homer, we chose to include this later publication (1902) of Tennyson's "Ulysses," not merely because he wrote 
it in blank verse, adapted from Paradise Lost, but because of the typographical beauty of this Doves Press publication, and the intriguing provenance. The Doves Press is considered second only to William Morris's influential Kelmscott Press as the most innovative and influential private press of the Typographic Renaissance of the late-nineteenth and early-twentieth centuries. In contrast to Kelmscott's Victorian propensity for lavish decoration, Doves books showcase a minimalist aesthetic, modeling restraint and spiritual intensity. Our copy of Seven Poems \& Two Translations is inscribed by "Annie Cobden-Sanderson and the printer" to Louis ShoreNightingale. Shore-Nightingale was the son of a close cousin of Florence Nightingale, the famous nurse. As we know, Florence was the daughter of a wealthy, upper-class British family who, because of what she believed was a message from God, gave up a life of ease and luxury to study nursing, and, eventually, serve with exemplary sacrifice as a nurse in the Crimean War. Her habit of making rounds at night led the poet, Henry Wadsworth Longfellow, to refer to her in his poem "Santa Filomena" as the "lady with the lamp." One feels the abstemious Florence would have approved of the Doves Press, and perhaps Annie Cobden-Sanderson felt the same way.

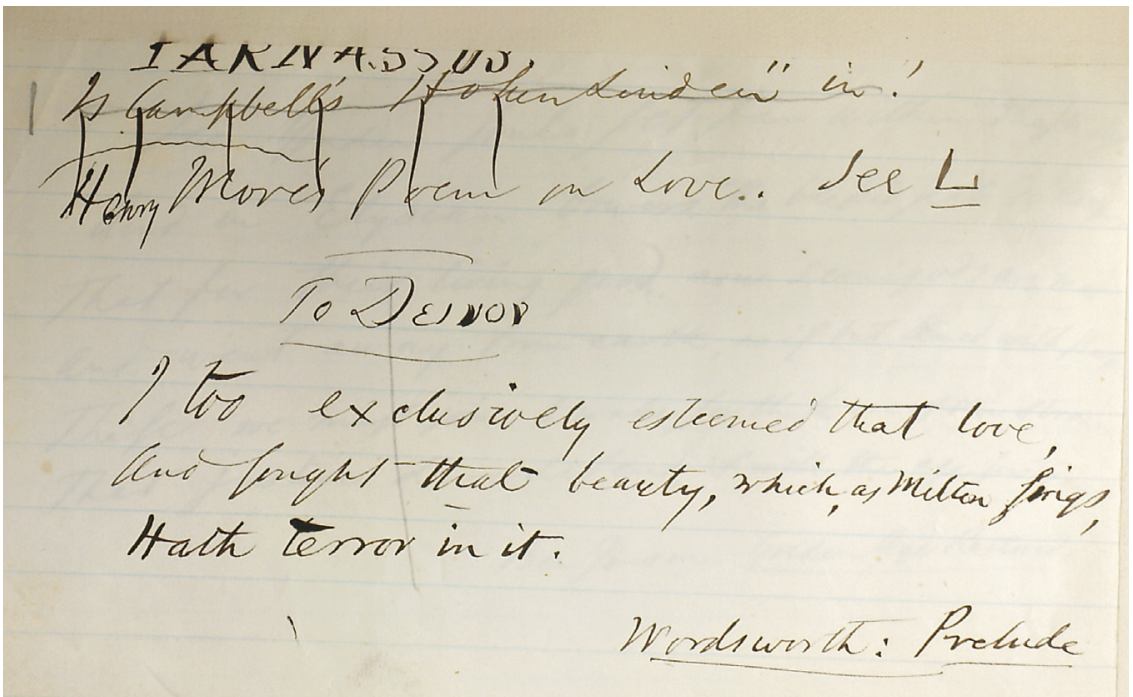

9.3 To mark the centenary of his birth, the Riverside Press dispersed one hundred of Emerson's manuscripts into copies of The Complete Works of Ralph Waldo Emerson (Cambridge, Riverside Press, 1903-04). In Rutgers' copy is a manuscript containing a stanza from The Prelude by William Wordsworth, which treats of Milton's descriptions of sublime beauty. 
Annie was the wife of T .J. (Thomas James) Cobden-Sanderson, the printer referenced in the inscription, and the Press's founder.

\section{Emerson, Ralph Waldo. The Complete Works of Ralph Waldo} Emerson; with a biographical introduction and notes by Edward Waldo Emerson (1903-04): vol. 1. ${ }^{12}$

What makes this edition of Emerson's works thrilling is the leaf of Emerson's manuscript bound into the front of volume 1. Evidently, in 1903, no harm to archival research was seen in the dispersion of Emerson's notes among six hundred volumes (the number of leaf-bearing volumes in the edition); perhaps the publishers assumed adding a manuscript would heighten library interest in this celebratory publication. What we cherish most about our copy is its almost uncanny appositeness for our uses. The Afterlife of John Milton might have been conceived expressly to show off this manuscript on which Emerson has copied lines 244-246 of Book XIV of The Prelude.

I too exclusively esteemed that love, And sought that beauty, which, as Milton sings, Hath terror in it.

This remarkable holograph derives from passages of The Prelude in which Wordsworth recollects a time he found the greatest value in stark summits and lofty waterfalls_-in what his contemporary, Edmund Burke, calls the sublime; but through Dorothy's kindness and patient example (the passages are directed to his sister), he has grown to perceive true beauty in humble nature. He believes these exquisite and conditioned perceptions have enabled him to imagine the greatness of a "more refined humanity." The correspondence between Wordsworth's lines and Emerson idea, the cornerstone inspiration of Transcendentalism, that one can intuit spiritual values in nature, leaps off the page. Here is a manuscript in the hand of one of the founders of Transcendentalism tracing its themes back to Wordsworth and indirectly to Milton. These marks on the page enable us to project ourselves smack into the Afterlife, and to imagine, we are gazing over Emerson's shoulder as he reflects on Wordsworth reflecting on Milton. Here is a vivid, impressive example of the conversation among texts that grounds our notion of a living literature, and a library. 
120

THE JOURNAL OF THE RUTGERS UNIVERSITY LIBRARIES

Pat of this Vinic was Bet up by "Mishears" wi a Camden

Priming office, "Fee urial Edition" and uso oed largely of then Aught frise uh o cane to his rescues when be was "pore!" sld andparayicy This Coifing was in his rom whens hester.
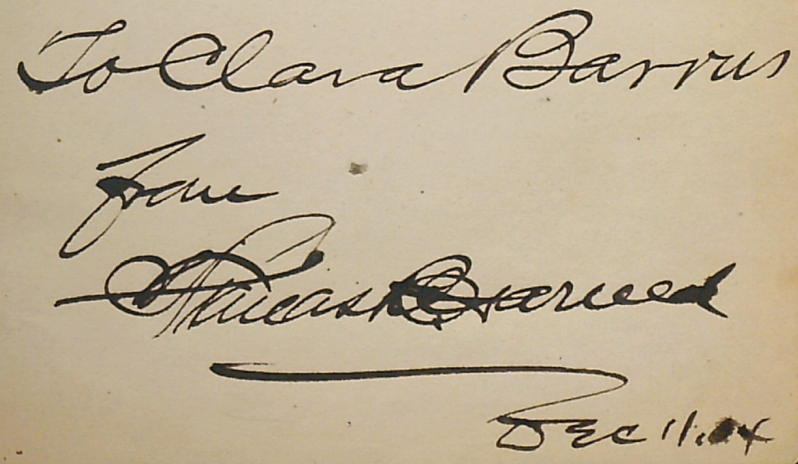

9.4 A letter written to Clara Barrus in funereal black ink on the front free endpaper of Whitman's Leaves of Grass (Camden, NJ, 1876), by Whitman's literary executor, Thomas Harmed. 
Whitman, Walt. Leaves of Grass (1876) ${ }^{13}$

The Rutgers Libraries' copy of Whitman's 1876 edition of Leaves of Grass is unquestionably one of its most extraordinary association copies. That it belonged to Whitman is attested by a holograph note on the fly leaf from the poet's friend and literary executor, Thomas B. Harned (after whom the great Whitman collection at The Library of Congress is named) written to the physician, Clara Barrus (Dec. 11, 1904).

Clara Barrus was a distinguished and barrier-breaking medical practitioner who maintained a two-decades long association with John Burroughs, the naturalist and author of Notes on Walt Whitman as Poet and Person (1871), the first biographical and critical work on the poet. Whitman knew John Burroughs quite well; he revised and edited Notes-extensively and anonymously_before publication. Although many years his junior, Clara Barrus was Burroughs' friend, secretary, biographer, and traveling companion. When he died, she took on the role of his literary executor. Among her works are two posthumous volumes of Burroughs' essays, and a biography, Whitman and Burroughs, Comrades (1931), composed with the assistance of Clifton Joseph Furness, the most distinguished Whitman scholar of his period.

In his lengthy inscription, virtually a letter written into the book, Harned informs Clara that part of this volume was set up in type by Whitman in a Camden Printing office and that it was sold largely to those English friends who came to his rescue when he was "poor, old and paralyzed." (See figure 6.4) The letter concludes with the even more poignant observation that this copy of Leaves of Grass was in his very room when Whitman died. Harned clearly intended his gift to move Clara deeply, and must have believed he was carrying out the will of the dying poet.

As if this weren't enough, the volume also bears a two page holograph letter to Whitman from Frederick Locker-Lampson, whom we remember as an author of light verse and a renowned book collector. (The name of his home, Rowfant, was later adopted by a book collectors club in Cleveland, calling itself The Rowfant Club.) Doubtlessly striving to cheer up the ailing Whitman, the chatty Locker-Lampson tells him that he has "often heard [Tennyson] speak of you, and always in a way that would be gratifying to you as Walt Whitman the Poet - \& Walt Whitman the Man" (dated 7 April 1880). The phrasing tells us that either Tennyson or Locker-Lampson, or both poets, were aware of 
Burroughs 1871 study, and lets us imagine that perhaps Whitman was cheered up.

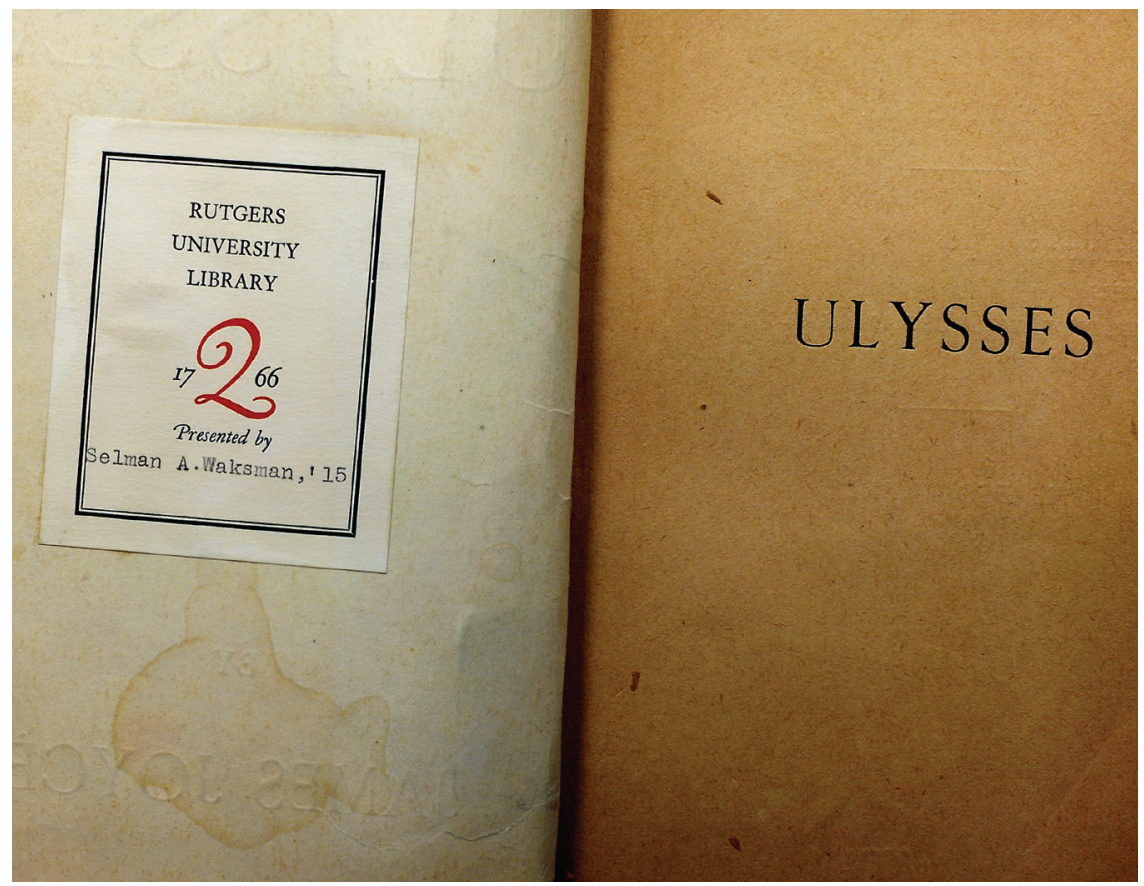

9.5 Half-title of James Joyces Ulysses (Paris: Shakespeare \& Co., 1924), with library presentation bookplate on front inside cover

Joyce, James. Ulysses (1924) ${ }^{14}$

Copies of the fifth printing of the first edition of Ulysses are rare, and yet once again it is the provenance of the Rutgers copy that makes this book irresistible. It was owned and given to the Libraries by Selman Waksman, a Rutgers alumni and professor awarded the Nobel Prize in 1952 for his work with streptomycin, the first antibiotic that could cure tuberculosis, of which he was the co-discoverer. Waksman would have picked up Ulysses while visiting Paris in 1924, the year it was published (a later state of the first edition published in 1922) and brought it back with him to the States. This commonplace act of buying a book abroad and bringing it home is, in the event, more interesting than it might seem, since the US Government had declared Ulysses obscene and, based on the serialized version published in Margaret Anderson's Little Review, banned it three years earlier in 1924 . 
The ban wouldn't be rescinded until December, 1933 . Therefore, the Rutgers Ulysses is actually the answer to the Jeopardy question, "What piece of contraband literature in the Rutgers University Libraries was smuggled into the country by a future Nobel laureate?"

Apart from its colorful history, a difficult, iconic literary work owned by a renowned scientist may strike us as a symbol of hope in these divisive times. In 1959, C.P. Snow delivered his influential lecture entitled "The Two Cultures," in which he posited his famous thesis of the two cultures; humanity's ability to solve the world's problems was impeded by the breakdown in communication between the sciences and the humanities. As a trained scientist and a successful novelist, Snow's accomplishments might have inspired one to believe that such impediments, steep as they may have appeared, might still be overcome with courage and imagination. Waksman's illegal Ulysses might be taken as another such symbol.

\section{Notes}

1. Libraries' copy the 2nd ed., printed for Bernard Lintott, at the CrossKeys in Fleetstreet, 1714. Despite Lintott's faithful service to him, Pope treated Lintott contemptuously in his Dunciad, among several lines beginning: "As when a dab-chick waddles thro' the copse, / On feet and wings, and flies, and wades, and hops; / So lab'ring on, with shoulders, hands, and head, / Wide as a windmill all his figure spread ..."

2. Libraries' copy the six volume London edition, printed by W. Bowyer, for Bernard Lintott, 1715-1720. The printing house of William Bowyer was considered the most learned publisher of its time. See The Bowyer Ledgers, ed. Keith Maslen and John Lancaster (London: The Bibliographical Society, 1991), xxv.

3. Libraries' copy issued in London by the Stationers Company, [1739?].

4. The Libraries own several eighteenth-century editions of Johnsons' Lives, including a 1781 and a 1784 . For this exhibition we displayed the 1790 London edition, printed for J. Rivington \& Sons.

5. The first edition of Wordsworth's Prelude appeared in London, in 
1850, printed by Edward Moxon, publisher also of Charles Lamb, Tennyson, and Browning. Moxon was himself an author of several books of poetry, including The Prospect and Other Poems (1826), Christmas (1829), and Sonnets (1830, 1835). His acquaintance with Wordsworth began in 1826, and lasted until Wordsworth's death in 1850 (see A Moxon Family Website: Edward Moxon, http://homepage. ntlworld.com/john.moxon/edwardmoxon.html).

6. Libraries' copy the 1st ed. of Endymion: A Poetic Romance, printed in London for Taylor and Hessey, 1818. (See James Robertson MacGillivray, Keats: A Bibliography and Reference Guide).

7. Libraries' copy the 1st. ed. of Moby Dick; or The Whale, published simultaneously in New York by Harper \& Brothers and in London by Richard Bentley, in 1851.

8. The exhibit featured two editions of Whitman's Leaves of Grass. A second issue of the first edition, famously printed by Andrew and James Rome in Brooklyn, 1855, and the 1876 so-called author's edition, discussed in this essay.

9. London: Printed and sold by T. Wilkins, Aldermanbury, MDCCXCIV [1794].

10. Peter Hunt, Understanding Children's Literature (New York: Routledge, 1999), 15.

11. Tennyson, Alfred, Seven Poems and Two Translations (London: Doves Press, 1902) .

12. Emerson, Ralph Waldo. The Complete Works of Ralph Waldo Emerson; with a Biographical Introduction and Notes by Edward Waldo Emerson and a General Index [Cambridge, Riverside Press, 1903-04].

13. Whitman, Walt. Leaves of Grass. Author's ed. With Portraits From Life (Camden, NJ, 1876).

14. Joyce, James. Ulysses (Paris: Shakespeare \& Co., 1924). 